\title{
Impact Of Different Extraction Methods On Physical Chemistry Properties Of Palm
} KERNEL OIL (ELAEISGUINEENSIS)

\author{
Ibrahim, A.1'),Sarifah Nurjanah ${ }^{2)}$, Ade M. Kramadibrata ${ }^{2)}$ \\ ${ }^{1)}$ Department of Food Science \& Technology, Faculty of Agriculture Science, Omdurman Islamic \\ University, P.O.BOX, www.oiu.edu.sd, Khartoum, Sudan \\ ${ }^{2}$ Faculty of Agro-Industrial Technology, University of Padjadjaran \\ Jalan Raya Bandung-Sumedang Km 21, Jatinangor 40600 \\ E-mail :ibrahim.sudann@gmail.com
}

\begin{abstract}
This study was conducted to assess the impact of oil extraction from kernel palm by two methods of extraction they are, mechanical press and solvent (hexane) extraction. The aim of this study was to determine the impact of extraction methods on physical chemistry properties of palm Elaeisguineensis kernel oil. Methods were used for extracting oil from palm kernel according to the method of Mandal and Lee, moreover physical chemistry analysis for oils was conducted by AOAC and AOCS methods. These results showed significant differences $(P<0.05)$ of the extraction method between five physical chemistry parameters. In these results number of saponification, peroxide, and iodine of oil that was extracted by hexane, while density was extracted mechanically and the results showed significant difference with the standards of FAO and WHO. The results showed that the number of each parameter from solvent (hexane) and mechanical press are Saponification $194.29 \pm 0.20 \mathrm{mgKOH} / \mathrm{g}$ and $215.74 \pm 1.29 \mathrm{mgKOH} / \mathrm{g}$, Peroxide $3.72 \pm 0.25 \mathrm{mgKOH} / \mathrm{g}$ and $3.39 \pm 0.31 \mathrm{mgKOH} / \mathrm{g}$, lodine $18.28 \pm 0.13$ $\mathrm{mgKOH} / \mathrm{g}$ and $22.8 \pm 0.23 \mathrm{mgKOH} / \mathrm{g}$, Density $0.87 \pm 0.01 \mathrm{~g} / \mathrm{cm}^{3}$ and $0.91 \pm 0.00 \mathrm{~g} / \mathrm{cm}^{3}$, Viscosity $27.66 \pm 1.15 \mathrm{~mm}^{2} / \mathrm{s}$ and $40.66 \pm 2.08 \mathrm{~mm}^{2} / \mathrm{s}$, FFA $1.33 \pm 0.17 \%$ and $1.83 \pm 0.04 \%$, respectively. The color of the oil were clear yellow by hexane extract and brown by mechanical extract. These results showed that the extraction methods of palm kernel oil by hexane is better than mechanical extraction.
\end{abstract}

Keywords: Palm kernel oil, Extraction, physic-chemical properties

\section{ABSTRAK}

Ekstraksi minyak inti sawit dapat dilakukan secara mekanik dan menggunakan pelarut (heksan). Tujuan dari penelitian ini adalah untuk menentukan dampak dari metode ekstraksi terhadap sifat kimia fisik dari minyak inti sawit (Elaeisguineensis). Metode yang digunakan untuk mengekstraksi minyak dari inti sawit sesuai dengan metode Mandal dan Lee, sedangkan analisis kimia fisik untuk minyak dilakukan dengan metode AOAC dan AOCS. Hasil ini menunjukkan perbedaan yang signifikan ( $P$ $<0,05)$ dari metode ekstraksi terhadap lima parameter kimia fisik. Dalam sejumlah hasil saponifikasi, peroksida, dan yodium minyak yang diekstraksi oleh heksana, sementara kepadatan diekstraksi mekanis dan hasilnya menunjukkan perbedaan yang signifikan dengan standar FAO dan WHO. Hasil penelitian menunjukkan bahwa jumlah masing-masing parameter dari pelarut (heksan) dan tekan mekanik penyabunan 194,29 $\pm 0,20 \mathrm{mgKOH} / \mathrm{g}$ dan 215,74 $\pm 1,29 \mathrm{mgKOH} / \mathrm{g}$. Peroksida 3,72 $\pm 0,25$ $\mathrm{mgKOH} / \mathrm{g}$ dan $3,39 \pm 0,31 \mathrm{mgKOH} / \mathrm{g}$, Yodium $18.28 \pm 0,13 \mathrm{mgKOH} / \mathrm{g}$ dan $22,8 \pm 0,23 \mathrm{mgKOH} / \mathrm{g}$, Kepadatan 0,87 $\pm 0,01 \mathrm{~g} / \mathrm{cm}^{3}$ dan 0,91 $\pm 0.00 \mathrm{~g} / \mathrm{cm}^{3}$, Viskositas 27,66 $\pm 1,15 \mathrm{~mm} 2 / \mathrm{s}$ dan 40,66 \pm $2,08 \mathrm{~mm} 2 / \mathrm{s}$, FFA $1,33 \pm 0,17 \%$ dan $1,83 \pm 0,04 \%$. Warna minyak yang berwarna kuning jernih dengan ekstrak heksana dan coklat dengan ekstrak mekanik. Hasil ini menunjukkan bahwa metode ekstraksi minyak inti sawit dengan heksana lebih baik dari ekstraksi mekanik.

Kata kunci: minyak inti sawit, Ekstraksi, sifat fisik-kimia

Diterima : 25 Mei 2016 ; Disetujui : 18 Agustus 2016 ; Online Published : 31 Oktober 2016

Impact Of Different Extraction Methods On Physical Chemistry Properties Of Palm Kernel Oil 


\section{INTRODUCTION}

Fats and oils are created from construction wedges so-called triglycerides resulting from the grouping of one unit of glycerol and three units of fatty acids. It is insoluble in water but soluble in most organic solvents, and they have less than the density of water. Fats are animal products, while oils are vegetable products. And can be a consistency at room temperature for solid and semi-solid, or pure liquid (Strayer, et al, 2006).

Palm Oil (Elaeisguineensis) is a tropical plant that reaches a tallness of 20-25 $\mathrm{m}$ with a life sequence of about 25 years. Full production is reached 8 years after establishing. Two kinds of oil are obtained from the fruit: palm oil proper, from the pulp, and palm kernel oil. Several high oil-yield varieties have been developed. Indonesia and Malaysia are the leading producers. International demand for palm oil has increased steadily during the past years. It is important to remark that pure palm oil is semisolid at room temperature, and in many submissions is mixed with other vegetable oils, sometimes moderately hydrogenated (Benjumea, 2004).

Worldwide palm oil production has improved from 15.2 million tons in 1995 to 54 million tons in 2014. This is the highest production size of all vegetable oils, exceeding the second biggest oilseed crop by more than 10 million tons. This capacity was generally created by Indonesia (50 \%) and Malaysia $(35 \%)$. There has also been a marked growth in palm oil production in other amounts of the world (E PO A, 2014).

In oil extraction, there are mainly three methods of eliminating oil from raw materials: dry processing or wet processing, solvent extraction and traditional methods of extraction. Solvent extraction is not suitable for small-scale processing because of high capital and operating costs. Equipment for wet or dry processing is available at different scales of operation from household to industrial scale (Tony, 2008).

The objective of the present study was to investigate the impact of extraction methods on the yield of oil and physic-chemical properties of palm oil kernel.

\section{MATERIALS AND METHODS}

The research planned to be conducted to on November 2015 to June 2016 at Postharvest, Pilot Plant, and Chemical Laboratories of Padjadjaran University (UNPAD).

The materials that used in this research were: seeds of palm, filter paper, Hexane (C6H12O6), sodium hydroxide $(\mathrm{NaOH})$, methanol $(\mathrm{CH} 3 \mathrm{OH})$, potassium iodine $(\mathrm{KI})$, $\mathrm{HCL}$, Phinonphthaline (pp), kalioum Hydroxide $(\mathrm{KOH})$, chloroform. Acitic acid, Yodiuom bromide (Brl), Distiled water (DW), Sodium Di selphate (Na2S2O4), Hgo, H2SO4, K2SO4, $\mathrm{Na} 2 \mathrm{~S} 2 \mathrm{O} 3, \mathrm{H} 2 \mathrm{O}, \mathrm{H} 3 \mathrm{BO} 3$.

The equipment that used in this research were: soxhlet, machine press, digital viscometer, pycnometer, thermometer, oven, sensitive balance, centrifuge, refrigerator, mixer, water bath, beakers, flasks, burets, pipets, dissector, erlenmeyer, bottles, dropper, spatulas, conical flask.

\section{COLLECTION OF SAMPLES}

Samples were collected from Bogor, west Java, Indonesia.

\section{Extraction Oil}

Extraction oil was conducted aaccording to the methods of (Mandal and Lee, 2013), The Oil was extracted using cold press extraction with small scale "expeller" (temperatures $40-60^{\circ} \mathrm{C}$ ). The filtered process was conducting by using centrifuge. Accelerated solvent extraction method was conducting by using solvent extractor (hexane). The working conditions of ASE were at oven temperature: $105^{\circ} \mathrm{C}$, pressure: 1500 psi, flush volume: $100 \%$, purge time: $60 \mathrm{~s}$, and fixed cycles: 3 times. Solvent was unconcerned under fume covering.

\section{PHYSIC-CHEMICAL ANALYSES OF EXTRACTED PALM KERNEL OIL}

lodine value, The AOAC Official Method 993.20 (Wijs method) was used to determine the lodine values. Oils weigh of $0.1-0.5 \mathrm{~g}$ Erlenmeyer closed, plus $10 \mathrm{ml}$ of chloroform carbon tetra chloride and iodine bromide reagent 25 (Attachment 21) and a regular in the dark for 30 minutes in all in the excavation,

12 Impact Of Different Extraction Methods On Physical Chemistry Properties Of Palm Kernel Oil

(Elaeisguineensis) 
then added a solution of $\mathrm{KI} 15 \%$ as much as $10 \mathrm{~mL}$ and add $50-100 \mathrm{mLof}$ hot distilled, titration with $0.1 \mathrm{~N} \mathrm{Na2S} 2 \mathrm{O} 3$ until the solution is pale yellow, added $2 \mathrm{~mL}$ starch solution, titration was continued until the blue color says, the reference solution made from $25 \mathrm{~mL}$ Reagent iodine bromide and add $10 \mathrm{~mL}$ solution $\mathrm{g} \mathrm{KI} 15 \%$ diluted with $100 \mathrm{~mL}$ of distilled water which boil and titrate with $\mathrm{Na2S} 2 \mathrm{O} 3$.

$$
\text { Iodine value }=\frac{[(\mathrm{B}-\mathrm{S}) \times \mathrm{N} \times 12.69]}{\text { Weight sample }}
$$

The Peroxide values will be determined according to the official methodno. 965.33 of the Association of Official Analytical Chemist (AOAC). The sample $M(0.5 \mathrm{~g})$ was taken to the nearest of $0.1 \mathrm{mg}$ in a conical flask, $30 \mathrm{~mL}$ of the acetic acid and chloroform (mixture 2:3) were added to it followed by $0.5 \mathrm{~mL}$ of a saturated potassium iodide solution. After 1 minute of occasional shaking, $30 \mathrm{~mL}$ of distilled water were added. It was titrated slowly with a $0.01 \mathrm{M}$ na2S2O3 solution with vigorous shaking until the disappearance of the yellow color, $0.5 \mathrm{~mL}$ of $1 \%$ starch indicator was added and titration continued till until the blue color had just disappeared. Peroxide value expressed in mol.ekivalen in peroxidase in $1000 \mathrm{~g}$ sample.

Peroxide number

$$
=\frac{\mathrm{ml} \mathrm{Na} 2 \mathrm{~s} 2 \mathrm{o} 3 \times \mathrm{N} \text { thio } \times 1000}{m g \text { sample }(g)}
$$

The saponification value of the palm oil kernel was determined according (AOCS, 1992) method of (Norziah, et, al, 2009). Oil sample $(1 \mathrm{~g})$ was dissolved in $12.5 \mathrm{ml}$ of $0.5 \mathrm{~N}$ ethanolic potassium hydroxide. The mixture was refluxed for 30 min until oil dewdrops missing and was left to cool to part of building temperature. Phenolphthalein indicator was then added and the hot soap solution was titrated with $0.5 \mathrm{~N} \mathrm{HCl}$ until the pink color gone. A blank titration was also passed out in the similar manner except no oil was further.

Saponification value $: \frac{28.05 \times(\text { titr blank }-\operatorname{titr} \text { sample })}{g \text { sample }(g)}$

Free fatty acids value was determined according to the method describe in AOCS,
1992. The amount of $5 \mathrm{~g}$ of sample oil was mixed with $75 \mathrm{ml}$ of $95 \%$ neutral ethyl alcohol and swirled. Phenolphthalein was added as indicator. The solution was titrated with $0.1 \mathrm{~N}$ sodium hydroxide until pinkish color was observed at end of the point. FFA values were determined from equation given in the method. From the FFA value, acid value (AV) was also calculated.

Levels of FFA as lauric $(\%)=\frac{\mathrm{mL} \mathrm{NaOH} \times \mathrm{N} \times 20}{\text { Sample weight }}$

The density of the oil was determined according to the method of Dabo et al, 2013. An empty beaker was weighed and the weight noted, then $50 \mathrm{~cm}^{3}$ of the sample (oil) was emptied into the beaker and weighed. From the sample weight obtained, the density was determined by taking the ratio of the weight of the oil to the known volume $\left(50 \mathrm{~cm}^{3}\right)$ in SI units according to the equation below:

$$
\text { Density }=\frac{\text { Sample weight }}{\text { sample volume }}
$$

The viscosity of the oils was determined by digital viscometer using spindle LI, rpm 100 (Siddique et, al, 2010).

The color characteristics of the palm oil kernel were determined by sighting (Olaniyi, 2014).

\section{STATISTICAL ANALYSIS}

The analyses were carried out in triplicates. Descriptive explanatory method will be employed to discuss the results. T-test will be performed to evaluate the difference between data by SPSS Version 16.

\section{RESULTS AND DISSCUTION}

This study was conducted to evaluate the impact of oil extraction from kernel palm by two methods of extraction; mechanical press and solvent (hexane). From the above table these results showed significant differences $(P<0.05)$ of the extraction method between five physical chemistry parameters, this study agree with Suganya et al., (2013). The work mentioned that the different seed extraction techniques influence the oil yield and the seed oils properties. The seed oils properties are highly influenced by the seed extraction 
techniques, and the effect of two different seed extraction techniques on some quality characteristics of seed oil. The techniques are referred as the hot and cold methods applied in extracting the oil obtained from the seeds and analyzed for its free fatty acids, peroxide, and iodine. As recommended by FAO and WHO (2010) guidelines of allowable value of Saponification 230-254 mg KOH/g, Peroxide < $15 \mathrm{mg} \mathrm{KOH} / \mathrm{g}$, lodine $14.1-21.0 \mathrm{mg} \mathrm{KOH} / \mathrm{g}$ ) Density $0.899-0.914 \mathrm{~g} / \mathrm{cm}^{3}$. According to the standards of FAO and WHO our results showed that the Saponification $194.29 \pm 0.20 \mathrm{H}$ - 215.74 $\pm 1.29 \mathrm{M}$, Peroxide $3.72 \pm 0.25 \mathrm{H}$ $3.39 \pm 0.31 \mathrm{M}$, lodine $18.28 \pm 0.13 \mathrm{H}-22.8 \pm 0.23$ $\mathrm{M}$, Density $0.87 \pm 0.01 \mathrm{H}-0.91 \pm 0.00 \mathrm{M}$ respectively. In these results Saponification, Peroxide and lodine that was extracted by hexane and density extracted mechanically showed significant difference with the standards of $\mathrm{FAO}$ and $\mathrm{WHO}$.

Table1: Physic-chemical properties of palm kernel oil

\begin{tabular}{|c|c|c|c|}
\hline No. & Parameters & 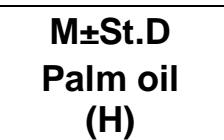 & $\begin{array}{l}\text { Palm oil } \\
\text { (M) }\end{array}$ \\
\hline 1 & Density $\mathrm{g} / \mathrm{cm}^{3}$ & $0.87 \pm 0.01^{a}$ & $0.91 \pm 0.00^{b}$ \\
\hline 2 & $\begin{array}{l}\text { Viscosity } \\
\mathrm{mm}^{2} / \mathrm{s}\end{array}$ & $27.66 \pm 1.15^{\mathrm{a}}$ & $\underset{b c}{40.66 \pm 2.08}$ \\
\hline 3 & Saponification & $194.29 \pm 0.2^{\mathrm{a}}$ & $\underset{b c}{215.74 \pm 1.29}$ \\
\hline 4 & $\begin{array}{l}\text { Peroxide } \\
\mathrm{mgKOH} / \mathrm{g}\end{array}$ & $3.72 \pm 0.25^{\mathrm{a}}$ & $3.39 \pm 0.31^{\mathrm{ac}}$ \\
\hline 5 & $\begin{array}{l}\text { lodine } \\
\mathrm{mgKOH} / \mathrm{g}\end{array}$ & $18.28 \pm 0.13^{a}$ & $22.8 \pm 0.23^{b c}$ \\
\hline 6 & FFA & $1.33 \pm 0.17^{\mathrm{a}}$ & $1.83 \pm 0.04$ \\
\hline 7 & Color & $\begin{array}{l}\text { clear } \\
\text { yellow }\end{array}$ & Brown ${ }^{b}$ \\
\hline \multicolumn{4}{|c|}{$\begin{array}{l}\text { abc: Significance different P\&lt; } 0.01 \\
\text { ab: Significance different P\&lt; } 0.05 \\
\text { aa: No significant } \\
\text { Where; } \\
\text { (H): palm kernel oil extracted by hexane, } \\
\text { (M): palm kernel oil extracted by Mechanical }\end{array}$} \\
\hline
\end{tabular}

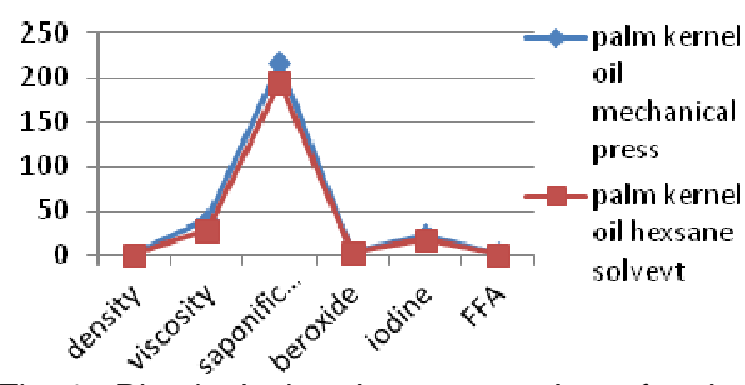

Fig 1. Physical chemistry properties of palm kernel oi

\section{CONCLUSION}

This study has established that the different methods extraction techniques influence the oil yield and the oil physical chemistry properties, moreover the extraction methods of palm kernel oil by hexane is better than mechanical extraction.

\section{ACKNOWLEDGMENTS}

We express our gratitude to UNPAD for funding and supporting this project. We also would like to thanks to Mr. Adi from the Laboratory of Chemistry (UNPAD), and to all to the laboratory staffs there.

\section{REFRENCES}

Strayer, Dennis.,Chairman and other, 2006, Ninth Edition, Food Fats And Oils, Institute of Shortening and Edible Oils 1750 New York Avenue, NW, Suite 120 Washington, DC 20006.

Agudelo Santamaría J R, Benjumea Hernández P N (2004) Biodiesel de aceite crudo de palma colombiano: aspectos de su obtención y utilización.

Siddique, BazlulMobin,et al., 2010, Physicochemical properties of blends of palm olein with other vegetable oils, Division of Environmental Technology, School of Industrial Technology, UniversitiSains Malaysia, 11800 Penang, Malaysia, issn: 0017-3495.

AOAC (2002).Official methods of analysis of the Association of Official Analytical Chemists (14th ed.), Arlington. 
AOCS.(1992). Official methods and recommended practices of the American Oil Chemists Society (4th ed.), Champaign, American Oil Chemists' Society, USA.

Olaniyi, Amira,P,et,al sept 20,2014,Physicochemical Properties of Palm Kernel Oil,Current Research Journal of Biological Sciences, ISSN:2041-076X, e-ISSN: 2041-0778.

Norziah.M.H., J. Nuraini, and K.Y. Lee, 2009. Studies on the extraction and characterization of fish oil from wastes of seafood processing industry. Asian Journal of Food and Agro-Industry ISSN 1906-3040.

European palm oil alliance, 2014, the palm oil story facts and figures.

Dabo, Mohammed.I.A., Kasim, Nuhu,M., Almustapha,I.M, and Yamusa.Y.A., 2013. Production of biolubricant from Jatrophacurcas seed oil, Journal of Chemical Engineering and Materials Science, ISSN 2141-6605.
SuganyaMurugesu, Abdul A. Ariffin, Tan C. Ping, Boo H. Chern 2013: Physicochemical Properties Of Oil Extracted From The Hot And Coldextracted Red Pitaya (HylocereusPolyrhizus) Seeds, J. Food Chem. Nutr. 01 (02) 2013.78-83.

FAO, and WHO, 2001, Fats and oils related products volume 8 the codex Aliment Arius Commission. ISBN 92-5-1046824.ISSN 0250-2916.

Mamta,Mandal and EunJoo Lee., 2013.Effects of Different Extraction Methods on the Chemical Properties of Cranberry Seed Oils.Department of Food and Nutrition, University of Wisconsin-Stout, Menomonie WI 54751, file:///E:/paper\%20new/mandal mamta c ranberry-1.pdf.

Tony Swetman, 2008. Oil extraction, Practical Action Technology challenging povrty. 